\title{
Peran Orang Tua terhadap Pembelajaran Mitigasi Bencana Bagi Anak Usia Dini di Masa Covid-19
}

\author{
Khambali Khambali ${ }^{\circledR}$, Dinar Nur Inten ${ }^{2}$, Dewi Mulyani' ${ }^{2}$, Funny Lichandra ${ }^{1}$, Dies Tiwi ${ }^{2}$ \\ Pendidikan Agama Islam, Universitas Islam Bandung, Indonesia(1) \\ Pendidikan Guru Pendidikan Anak Usia Dini, Universitas Islam Bandung, Indonesia( ${ }^{(2)}$ \\ DOI: $10.31004 /$ obsesi.v6i3.1866
}

\begin{abstract}
Abstrak
Penelitian ini didasarkan akan pentingnya orang tua dalam mendukung ketercapaian tujuan pembelajaran dalam mengenalkan dan mengembangkan pemahaman tentang mitigasi bencana bagi anak usia dini di masa pandemi Covid-19. Tujuan penelitian ini yakni untuk mengkaji peran orangtua dalam pembelajaran mitigasi bencana. Metode penelitian yang digunakan adalah kualitatif deskriptif melalui penyebaran angket terhadap 62 orang tua anak usia dini. Dalam penelitian ini terdapat beberaoa focus pertanyaan terkait: Orangtua menyiapkan tas siaga bencana di dalam rumah; Orang tua mengajarkan selalu bersyukur dan bersabar atas musibah; Kelekatan anak, dan Orang tua membantu menyiapkan media pembelajaran mitigasi bencana. Hasil penelitian menghasilkan kesimpulan bahwa orang tua membantu dalam mengenalkan tentang konsep dan cara sederhana terkait mitigasi bencana juga adanya penyampaian Al-Quran dan hadits serta mahfudzot terkait mitigasi yang diramu melalui metode diskusi dan bercerita serta media yang menarik sehingga anak merasakan senang dan dapat menyampaikan ide serta gagasan terkait mitigasi dengan nyaman dan terwujudlah pembelajaran bermakna.
\end{abstract}

Kata Kunci: anak usia dini; mitigasi bencana; orang tua.

\begin{abstract}
This research is based on the importance of parents in supporting the achievement of learning objectives in introducing and developing an understanding of disaster mitigation for early childhood during the Covid-19 pandemic. The purpose of this study is to examine the role of parents in learning disaster mitigation. The research method used is descriptive qualitative through the distribution of questionnaires to 62 parents of early childhood. In this research, there are several focus questions related to: Parents prepare disaster preparedness bags at home; Parents teach to always be grateful and patient for calamities; Children's attachments, and parents help prepare disaster mitigation learning media. The results of the study concluded that parents helped in introducing simple concepts and methods related to disaster mitigation as well as the delivery of the Koran and hadith and mahfudzot related to mitigation which were mixed through discussion and storytelling methods and interesting media so that children felt happy and could convey ideas and ideas related to mitigation comfortably and meaningful learning is realized.
\end{abstract}

Keywords: parents; disaster mitigation; early childhood.

Copyright (c) 2021 Khambali Khambali, et al.

$\triangle$ Corresponding author:

Email Address : khambali@unisba.ac.id (Bandung, Jawa Barat, Indonesia)

Received 15 July 2021, Accepted 2 November 2021, Published 8 November 2021 


\section{PENDAHULUAN}

Dunia di belahan manapun pasti memiliki kerawanan terhadap bencana. Bencana bukan hanya merengut banyak nyawa, tetapi juga merusak harta dan benda yang dimiliki manusia. Pusat Penelitian Epidemiologi Bencana (CRED, 2018) memaparkan, ada 11.804 kematian dari 315 peristiwa bencana yang terjadi pada 2018. Munich RE menunjukkan terdapat tingkat sebab dan akibat yang tinggi ketika melaporkan sebuah bencana (International Insurance Institute., 2020), karena bencana alam yang terjadi pada tahun 2019 telah menyebabkan sekitar 9.000 orang kehilangan nyawa dengan 820 peristiwa dengan sejumlah kerugiannya.

Salah satu negara yang memiliki kerawanan paling tinggi di dunia adalah Indonesia, dengan sejumlah potensi bencana yang mengintainya, seperti gunung berapi, tanah longsor, tsunami, angin putting beliung, gempa bumi, termasuk banjir. Setiap tahunnya, bencana alam yang terjadi sebanyak 289 kali dengan rata-rata kematian setiap tahun mencapai 8.000 peristiwa dalam tenggang waktu 30 tahun terakhir (GFDRR, 2020). Di Indonesia, setiap lima tahun sekali tsunami besar dapat saja terjadi dengan setidaknya terdapat satu letusan gunung berapi, karena Indonesia terletak di cincin api pasifik (UNDP, 2020).

Anak-anak merupakan anggota masyarakat yang paling rentan jika bencana terjadi karena anak-anak merupakan individu yang lemah dan masih membutuhkan perlindungan, berdasarkan hasil penelitian (Haleemunnissa et al., 2021), menunjukkan bahwa anak-anak memiliki resiko yang paling besar menjadi korban bencana dan terpapar virus serta mengalami kematian. Dan bencanapun memberikan efek negative terhadap tumbuh kembang anak, karena anak harus mengalami ketakutan, depresi dan harus bertahan di tempat berlindung yang aman tanpa adanya interaksi atau kegiatan bermain yang sangat mereka sukai. Hal ini menyebabkan timbulnya post-traumatic stress disorder Haleemunnissa. $\mathrm{S}$, et al:2020. Oleh karena itu dibutuhkan strategi pembelajaran terpadu dengan pendekatan kasih sayang, menyenangkan serta sarat dengan nilai-nilai ke-Ilahian agar mereka kembali dapat hidup normal dan menjadi hamba yang bersyukur atas semua kehendak-Nya.

Dari segi proses terjadinya bencana, anak-anak memiliki kerentanan baik itu sebelum, selama, maupun setelah bencana itu terjadi dengan sejumlah gangguan yang menimpa pada kehidupan anak-anak. Gangguan tersebut berimplikasi pada kehidupan keluarga, sekolah, kesehatan, pertemanan, tempat tinggal, dan bidang kehidupan lainnya; dengan berbagai resiko pada anak-anak seperti berpisahnya antara anak dengan orang tuanya, hilangnya tempat tinggal, sakit, cedera, atau kematian (Fothergill, 2017). Anak-anak merasakan kesusahan yang disebabkan oleh bencana karena bencana dapat mempengaruhi kesehatan mental dan kesejahteraan anak selama bertahun-tahun bahkan setelah bencana terjadi.

Bencana yang menimpa anak-anak dapat menimbulkan buntut serius bagi fungsi sosial dan kesehatan mental anak-anak (Bryant et al., 2018; Norris et al., 2002). Pada jangka waktu yang panjang, efek psikologis bencana yang beragam dapat pulih dengan cepat, sementara keadaan lainnya dapat memicu psikopatologi yang meliputi PTSD, anxiety, depresi berat, dan bahkan bisa menimbulkan penyalahgunaan obat terlarang. Tidak hanya itu, dampak bencana alam lainnya mampu mempengaruhi kemampuan belajar anak-anak dalam kurun waktu panjang, perubahan perilaku anak yang menjadi lebih agresif, dan penurunan prestasi belajar anak (Scott et al., 2014; Shultz et al., 2017; Greenberg et al., 2002).

Seringkali anak usia dini dianalogikan sebagai pihak yang tidak berdaya, lemah, rapuh, pasif, dan memiliki ketidakmampuan dalam segala hal. Meski begitu, terkadang anakanak dapat memperlihatkan keinginan serta kapasitas yang luar biasa ketika berhadapan dengan bencana yang tanpa disadari mereka mampu menyelamatkan dirinya sendiri maupun orang lain. Anak-anak bukan makhluk pasif, sehingga pemikiran dan perasaan mereka yang muncul akibat adanya bencana perlu dipahami dan mereka perlu diberi pemahaman mengenai bagaimana caranya bereaksi terhadap rasa takut, menepis ketakutan tersebut, dan menciptakan prosedur yang luwes untuk bertahan hidup. Dalam konteks ini kemampuan 
anak-anak perlu diperhitungkan dalam menghadapi beragam kerumitan dan rintangan hidup (Osofsky \& Reuther, 2013). Sehingga, anak-anak perlu diajari bagaimana cara menghadapi bencana sedari dini. Kousky (2016) menyatakan bahwa mitigasi bencana sangat penting dilakukan pada anak usia dini agar anak dapat bangkit Kembali menjalani kehidupannya setelah bencana menimpa.

Anak-anak juga merupakan individu yang mampu terlibat dan memiliki kemungkinan untuk mendukung keluarga dalam bersiapsiaga dan rehabilitasi masyarakat karena mereka adalah makhluk yang aktif dan kreatif. Ketika anak-anak memiliki sumber daya yang lebih dalam dirinya seperti kehadiran keluarga dan orang-orang di lingkungan komunitasnya, mereka dapat bangkit kembali (Osofsky \& Reuther, 2013). Hal yang perlu diperhatikan adalah bahwa anak-anak harus didekatkan aksesnya menuju sumber daya pendukung, memantapkan mereka agar mampu mendukung dan menempa pribadi mereka menjadi tangguh (resilient) dan mampu berdiri kembali setelah mengalami masa-masa sulit.

Informasi yang bermuatan bencana alam dan telah disesuaikan dengan usia anak harus ditampilkan kepada anak-anak. Mengenalkan perihal bencana alam kepada anak dengan cara yang mudah dan murah ialah dengan cara melalui buku bacaan anak. Dalam hal ini, visual cetak dan elektronik akan membuat anak-anak terbuka pada media simbolis (Raynaudo \& Peralta, 2019). Media pembelajaran bagi anak yang sering digunakan ialah buku bergambar. Permatasari. A.N, et al: 2018 Sebagai contoh dalam mengenalkan astronomi kepada anak melaui media big book mampu menjadikan anak usia dini menciptakan bentuk tiruan, dan menangkap makna pesan yang disampaikan. Dalam konteks ini, buku bergambar berfungsi sebagai media utama untuk mendapatkan kata dan bahasa baru, mengerti persepsi, dan berperan sebagai media edukatif bagi anak-anak. Buku bergambar mampu memberi akses konten yang biasa tidak anak-anak alami dan hal ini menjadi salah satu manfaat dari buku bergambar sebagai sumber utama pendidikan (Strouse et al., 2018).

Anak-anak perlu dilatih dan diberikan pemahaman terkait menghadapi bencana alam dan non alam, terutama bencana yang diakibatkan oleh adanya pandemi Covid-19, supaya mereka siap dalam menghadapinya. Selain itu, mereka perlu diberi pemahaman untuk mengetahui bagaimana seharusnya mereka bertindak saat bencana terjadi dan setelah bencana terjadi. Saat ini, pandemi Covid-19 yang melanda seluruh dunia dikategorikan sebagai bencana non alam yang diakibatkan oleh persebaran virus, yaitu virus corona. Semenjak diumumkannya Covid-19 (Corona Virus Disease-19) sebagai pandemi global, berita tentang hal ini telah menjadi asupan informasi harian bagi masyarakat Indonesia dan banyak negara di dunia. Pengumuman mengenai status pandemic global disampaikan oleh Direktur Jenderal Tedros Adhanom Ghebreyesus dari organisasi kesehatan dunia (WHO) setelah jumlah infeksi telah mencapai angka lebih dari 121.000 kasus di seluruh dunia (Utomo, 2020 ; World Health Organization, 2020).

Covid-19 adalah penyakit menular dari varian corona virus yang persebarannya pertama kali di temukan di Wuhan, Tiongkok, pada Desember 2019 silam. Beberapa tanda umum yang sering muncul akibat terkontaminasi virus ini antara lain kelelahan, demam, batuk, rasa nyeri sakit, hidung tersumbat, diare, serta nyeri tenggorokan. Penyebaran virus ini dapat terjadi dari manusia ke manusia melalui percikan-percikan dari hidung atau mulut ketika batuk atau bernafas dari seseorang yang sudah terjangkit Covid-19 sebelumnya. Ketika percikan yang mengandung virus itu tersebar di udara maupun menempel di permukaan benda kemudian tersentuh oleh seseorang dan tangannya kemudian menyentuh mata, hidung, serta mulutnya, maka besar kemungkinannya seseorang tersebut akan terjangkit Covid-19 (Indonesia, 2020; CNN Indonesia, 2020).

Pemerintah Indonesia kemudian mengeluarkan kebijakan yang dikenal sebagai Pembatasan Sosial Berskala Besar (PSBB) dengan maksud sebagai tindakan preventif dalam mengurangi jumlah penularan virus Covid-19 yang melonjak. Pemberlakuan kebijakan ini 
mengakibatkan beberapa hal, yakni adanya pengaruh signifikan dalam beragam unsur kehidupan di tengah-tengah masyarakat, baik itu pada sektor kesehatan, ekonomi, sosial, budaya, hukum, politik, dan pendidikan dari level perguruan tinggi hingga level anak usia dini.

Selama anak belajar daring di rumah, peran orang tua dalam mendukung keberhasilan belajar anak menjadi strategis, sehingga berkaitan dengan hal itu, WHO (2020) kemudian mempublikasikan panduan untuk para orang tua dalam mengambil peran terkait pendampingan anak-anak di masa pandemi yaitu dengan memaparkan langkah-langkah pengasuhan selama di rumah agar tetap positif dan membangun. Sebelum terjadi pergeseran pola didikan selama pandemi, pada awalnya orang tua hanya berperan dalam mengajari sikap dan keterampilan dasar untuk anak, seperti pendidikan agama, menaati peraturan, dan kebiasaan baik anak (Nurlaeni \& Juniarti, 2017), tapi kini fungsi orang tua menjadi semakin banyak dan meluas, yakni orang tua turut berperan sebagai pendamping pendidikan akademik bagi anak. Prabhawani (Prabhawani, 2016) memaparkan bahwa penyelenggaraan pendidikan adalah tanggung jawab orang tua dan masyarakat sekitar, bukan hanya dilimpahkan kepada lembaga pendidikan. Berpedoman pada hasil riset, pandemi Covid-19 membuat setiap individu dalam keluarga mampu untuk menjalankan peran dengan baik dan menyampaikan segala hal terkait peran yang dimilikinya agar mampu menciptakan kedekatan antara orang tua dan anak (Permatasari, A.N, et al 2021).

Membahas terkait kedudukan orang tua, pasti tidak akan terhindar dari keluarga. Lestari (2012) memaparkan bahwa keluarga memiliki beberapa fungsi, antara lain fungsi pemulihan, fungsi sokongan emosi dan materi, serta fungsi pemenuhan terhadap suatu peran tertentu. Konsisten dengan hal itu, Muchtar dalam artikel Lutfatulatifah (2015) menuliskan jika keluarga menjadi elemen penting dalam unit masyarakat yang ada karena keluarga berperan krusial dalam menjaga, mengajari, melindungi, dan menuntun anak. Menurut Candra et al. (2017) pembentukan karakter dan perilaku anak dipengaruhi oleh pola asuh orang tua kepada anak. Jika orang tua melakukan kesalahan dalam pola asuh terhadap anak, maka hal ini akan berimplikasi terhadap anak-anak ketika telah dewasa. Berangkat dari pernyataan tersebut, Rakhmawati (2015) juga menulis bahwa kegiatan berkelanjutan yang terjadi melibatkan tahapan interaksi antara orang tua dan anak dalam rangka mendorong tumbuh kembang anak secara optimal, hal disebut disebut sebagai pengasuhan anak. Pernyataan tersebut merujuk pada situasi yang terjadi selama ini bahwa posisi orang tua dalam mengasuh dan merawat anak terlihat mencolok, sehingga pendidikan yang sifatnya akademik sering kali dilimpahkan pada pihak lembaga sekolah, sebagaimana yang dinyatakan oleh Novrinda et al. (2017), orang tua beranggapan bahwa sekolahlah yang memiliki kewajiban terbesar dalam mendidik anak sehingga sebagain besar orang tua mempercayakan dan menumpukan harapan yang tinggi pada sekolah.

Riset terdahulu terkait topik mitigasi bencana pada anak usia dini diantaranya dilakukan oleh Nuraeni et al. (2020) Dengan kajian terkait Manajemen Mitigasi Bencana pada Satuan Pendidikan Anak Usia Dini untuk Pengurangan Risiko bencana Gempa Bumi dan Tsunami. Hasil studi yang dilaksanakan Nuraeni dkk menyimpulkan bahwa; manajemen bencana yang baik dapat dilakukan dengan tiga tahap, yaitu; tahap planning pra-bencana, dimaksudkan untuk meningkatkan kesiap-siagaan aturan, alat, fisik dan mental masyarakat terdampak; tahap implementation saat peristiwa terjadi, dimaksudkan untuk melakukan penyelamatan sesuai dengan standar operasional yang ditetapkan; dan tahap recovery pasca-bencana, dimaksudkan untuk melakukan pemulihan fisik dan mental masyarakat terdampak; Adapun penguatan manajemen bencana melaui pendidikan sejak dini dalam bentuk penerapan kurikulum pembelajaran kebencanaan di tingkat satuan PAUD (Nuraeni et al., 2020)

Riset terdahulu lainnya dilakukan oleh Hayudityas tahun 2020 tentang pentingnya penerapan pendidikan mitigasi bencana di sekolah. Hasil menunjukkan bahwa sekolah cukup 
siap menghadapi bila bencana terjadi dengan hasil pada siklus pertama $69 \%$ mengalami peningkatan menjadi 74\% dengan persentase gain yaitu 8\% (Hayudityas, 2020).

Penelitian terdahulu lainnya dilakukan oleh Rijal, A. S., Matalapu, I., Jaya, R., \& Maulana (2021), hasil penelitian menunjukkan bahwa informasi mitigasi bencana paling banyak di ketahui dari bangku sekolah serta dari berbagai sumber media. Mitigasi bencana yang sering terjadi seperti gempa bumi, banjir dan tanah longsor sering dialami oleh masyarakat, siswa dan guru sehingga perlu adanya tempat evakuasi yang siap siaga untuk ditempati. Kurangnya kesadaran masyarakat untuk mengikuti organisasi tentang mitigasi bencana membuat sebagian besar masyarakat tidak mengetahui tentang kesiapsiagaan dalam mengahdapi bencana yang akan terjadi. Kegiatan praktik mitigasi bencana yang diajarkan di sekolah merupakan salah satu solusi untuk mengajarkan siswa agar lebih memahami tentang cara menyelamatkan diri dari bencana dan tidak mudah panik serta takut.

Adapun riset yang dilakukan tim peneliti ini berbeda. Tujuan dari penelitian ini adalah memberikan gambaran peran orang tua dalam ikut serta menyukseskan pembelajaran bagi anak usia dini di rumah terkait dengan pembelajaran mitigasi bencana, baik itu dari segi materi, metode, media dan evaluasi pembelajaran. Dengan begitu, pembelajaran yang ditargetkan tujuan pembelajaran oleh guru di masa Covid-19 ini dapat tercapai sesuai dengan tujuannya dengan melibatkan orang tua di rumah.

\section{METODOLOGI}

Penelitian ini menggunakan pendekatan kualitatif dengan jenis penelitian deskriptif. Peneliti menggunakan jenis pendekatan penelitian kualitatif guna mendapatkan perspektif dan ilustrasi baru terkait peran dan bagian orang tua dalam edukasi mitigasi bencana untuk anak usia dini sebagai siswa yang harus menjalani program Study From Home (SFH) yang disebabkan oleh merebaknya wabah Covid-19 di Indonesia. Penelitian ini melibatkan sebanyak 62 orang tua dari siswa PAUD Sekabupaten Bandung. Penelitian ini diselenggarakan sejak tanggal 1 Maret 2021 ketika kebijakan SFH mulai diterapkan di PAUD/TK Se-Kabupaten Bandung, yaitu: KB. Az-Zahrah, TK Ummah Mariam, RA AlFaruuq, dan RA Al-Muqoddasah, hingga tanggal 28 Mei 2021. Peneliti melakukan beberapa rangkaian penelitian yang digambarkan sebagai berikut.

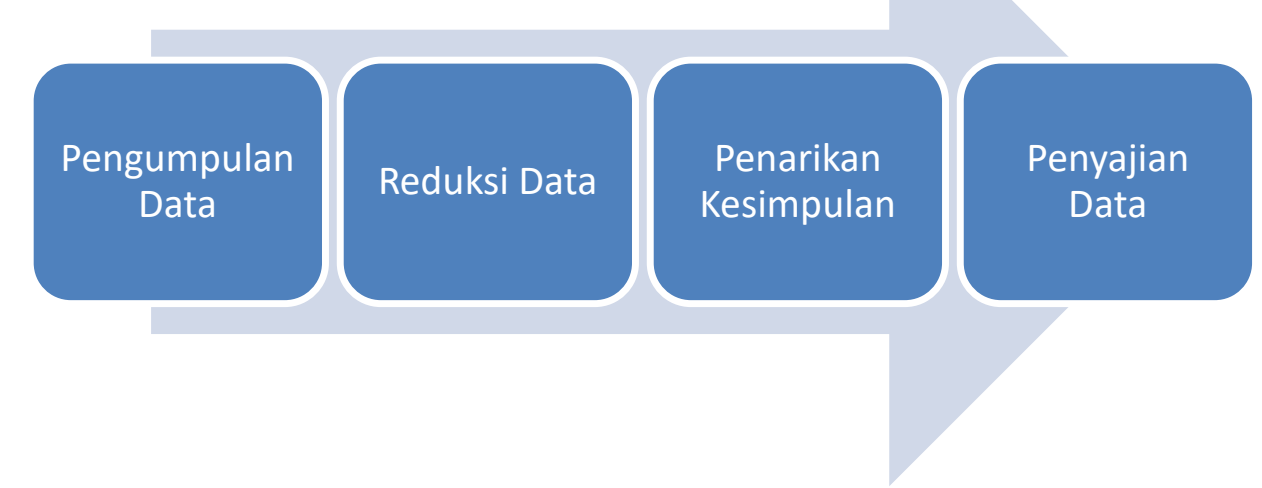

Gambar 1. Tahapan dalam Penelitian

Subjek dalam penelitian ini adalah 62 orang tua peserta didik KB/TK/PAUD di 4 KB/TK/PAUD di Kabupaten Bandung, yaitu: KB. Az-Zahrah, TK Ummah Mariam, RA AlFaruuq, dan RA Al-Muqoddasah. Sementara itu, peneliti melakukan kegiatan menganalisis dan mengamati data-data yang diperoleh untuk kemudian melaporkan hasil dari penelitian yang dilaksanakan. Penelitian ini menggunakan teknik pengumpulan data berupa teknik penyebaran kuesioner yang terstruktur untuk mengolektifkan berbagai informasi dan data yang dibutuhkan oleh peneliti sehubungan dengan penelitian yang dilakukan. 


\section{HASIL DAN PEMBAHASAN}

Mitigasi bencana meliputi kegiatan merencanakan dan melaksanakan aksi-akasi guna meminimalisasikan risiko serta dampak yang akan terjadi akibat suatu bencana, hal ini mencakup tiga fase, yaitu (a) pra bencana mencakup kegiata preventif, penahanan, kesiapsiagaan, dan peringatan dini terkait dengan bencana potensial di suatu daerah tertentu, (b) kegiataan pada saat bencana terjadi di suatu wilayah, meliputi kegiatan tanggap darurat, pencarian dan penyelamatan (search and resque), evakuasi, dan mempersiapkan pengungsian, serta (c) kegiatan pascabencana yang meliputi kegiatan penyembuhan, pemulihan, dan rekonstruksi bencana (Pemerintah Republik Indonesia, 2007).

Dewasa ini, kedudukan orang tua dalam mendidik anak usia semakin penting terlebih sejak adanya peristiwa pandemi Covid-19. Hal demikian menjadikan keluarga memainkan peran dan fungsinya sebagai pusat segala kegiatan, terutama kegiatan edukasi di dalam lingkungan keluarga untuk anak usia dini. Berdasarkan hasl kuesioner menunjukkan bahwa orang tua yang mengisi kuesioner adalah terdapat 62 orang tua yang berasal dari 4 lembaga Pendidikan KB/TK/PAUD di Kabupaten Bandung, yaitu: KB. Az-Zahrah, TK Ummah Mariam, RA Al-Faruuq, dan RA Al-Muqoddasah.

Orang tua yang mengisi kuesioner adalah memiliki pendidikan tingkat SD 7 orang, tingkat SMP 10 orang, tingkat SMA/SMK/MA 40 orang, dan tingkat Sarjana 4 orang. Pekerjaan orang tua anak usia dini yang mengisi kuesioner, yaitu: ibu rumah tangga sebanyak 19 orang; buruh pabrik 22 orang; wiraswasta sebanyak 7 orang; karyawan swasta sebanyak 10 orang; TNI Angkatan darat sebanyak 1 orang; Pekerja bangunan 1 orang; pengemudi 1 orang; dan tukang jahit 1 orang.

\section{Menyiapkan Tas Siaga Bencana}

Istilah Emergency Preparedness Kit atau yang lebih umum diketahui dengan sebutan Tas Siaga Bencana merupakan beragam barang-barang kebutuhan rumah tangga dasar yang disiapkan sebelum bencana datang dan akan dibutuhkan dalam keadaan emergency. Barangbarang pada daftar tabel ceklis harus dipastikan dilengkapi dalam Tas Siaga Bencana. Barangbarang pada daftar tersebut sebagian besar dapat diperoleh dengan murah dan mudah. Salah satu item dari barang-barang tersebut dapat menyelamatkan hidup keluarga, khususnya anak-anak, sehingga merupakan hal krusial dalam menghadapi bencana. Persediaan item untuk bayi, anak-anak, lansia, serta hewan peliharaan juga perlu dipertimbangkan dalam memenuhi kebutuhan khusus yang mungkin diperlukan. Tas siaga bencana ini memiliki fungsi untuk bertahan hidup selama beberapa hari, khususnya dalam kondisi terburuk akibat bencana, yang berisi persediaan penting yang harus dipersiapkan seperti air minum, makanan, dan persediaan lain yang harus mampu menyokong keadaan darurat keluarga setidaknya selama 72 jam atau 3 hari (BPBD, 2019).

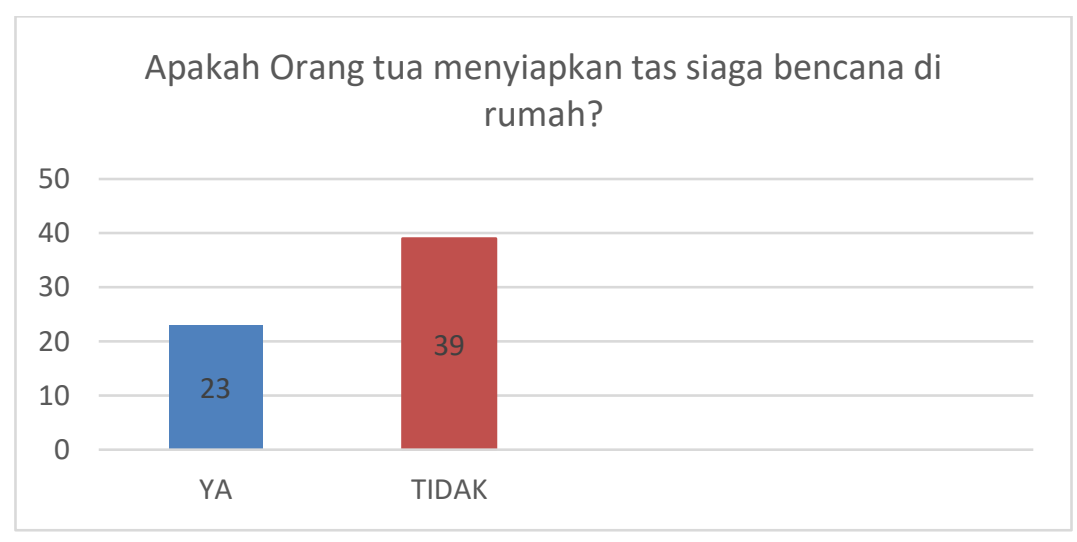

Grafik 1. Orang Tua Menyiapkan Tas Siaga Bencana 
Berdasarkan grafik 1 merupakan hasil kuesioner yang disebarkan kepada 62 orang tua dari anak usia dini yang tersebar di Kabupaten Bandung, diperoleh jawaban bahwa terdapat $62,9 \%$ orang tua yang tidak menyiapkan tas siaga bencana, dan 37,1 orang tua menyiapkan tas bencana. Kurangnya pengetahuan dan pemahaman orang tua mengenai betapa pentingnya tas siaga, terlebih apabila orang tua tinggal di daerah yang jarang terkena bencana, menyebabkan tingginya angka orang tua yang tidak mempersiapkan tas bencana. Berkat data tersebut maka pembekalan mitigasi bencana untuk orang tua perlu dilakukan untuk menyiapkan orang tua siaga bencana. Berdasarkan hasil penelitian Inten, D.N., et al : 2021, pembelajaran mitigasi anak usia dini sebaiknya selalu melibatkan dan menjadikan orang tua sebagai mitra belajar agar berdampak pada peningkatan kesadaran orang tua terhadap bencana untuk ikut berpartisipasi terhadap edukasi mitigasi di rumah dengan menggunakan media, alat, serta langkah-langkah sistematis pembelajaran yang diketahui oleh orang tua.

Pertimbangan orang tua dan anak dalam memilih tas siaga bencana dipengaruhi oleh beberapa aspek ergonomis, antara lain ukuran tas yang memakai data antropometri, kenyamanan pada desain alas punggung dan tali utama tas, penempatan barang pada tas yang memakai sekat-sekat agar memudahkan dalam mengambil atau meletakan barang, dan berat tas yang berada dibawah batasan angkat menurut ILO. Aspek lain yang diperhatikan adalah kapasitas tas yang cukup untuk menampung kebutuhan selama 1x24 jam masa evakuasi sesuai buku saku tanggap tangkas BNPB tahun 2017 dengan estimasi harga yaitu Rp. 202.100,- (Havis, 2020)

\section{Meminta Anak untuk Bercerita terkait Bencana}

Berdasarkan hasil kuesioner yang disebarkan kepada 62 orang tua dari anak usia dini yang tersebar di Kabupaten Bandung, diperoleh jawaban bahwa terdapat 90,3\% anak yang banyak bercerita tentang bencana; dan 9,7\% anak yang tidak bercerita tentang bencana. Anak akan menciptakan pengalaman dan memperoleh pengetahuan melalui bercerita secara lisan. Melalui cara ini, anak mampu mengembangkan, melatih kemampuan mengingat dan mengulang kembali materi yang telah disampaikan sebelumnya (Hajrah, 2018). Bercerita adalah bentuk komunikasi yang dapat membawa pendengarnya terlibat dengan isi cerita (Kumoro, 2015). Pada saat bercerita, terjadi proses yang menciptakan kesan menyenangkan dan menciptakan pengalaman seorang anak dan tugas guru. Bercerita tidak hanya menggunakan media buku, tetapi juga dapat menggunakan media lain, yakni boneka. Bercerita juga dapat dilengkapi dengan penggunaan media audio-visual.

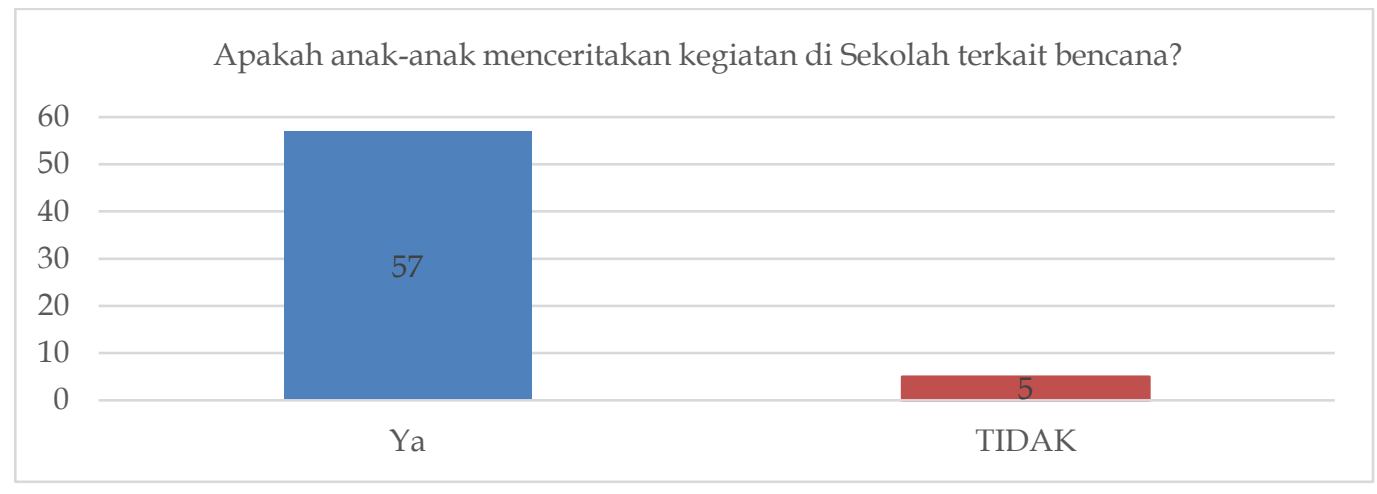

Grafik 2. Bercerita tentang Kegiatan Mitigasi Bencana di Sekolah

Grafik 2 menjelaskan hasil kuesioner yang disebarkan kepada 62 orang tua dari anak usia dini yang tersebar di Kabupaten Bandung, diperoleh jawaban bahwa terdapat 91,9\% anak yang bercerita kepada orang tuanya, dan $8,9 \%$ anak yang tidak bercerita terkait bencana. Hasil penelitian menekankan bahwa pemahaman mengenai bencana alam telah dapat dimiliki oleh 
anak usia dini yang berusia 5-6 tahun. Meskipun demikian, perlu menjadi pemahaman bahwa indikator pemahaman tentulah yang sesuai karakteristik kemampuan anak usia dini.

Pemahaman adalah suatu bentuk kemampuan kognitif dimana seorang anak mendapat pengetahuan melalui eksplorasi dan manipulasi secara elaboratife. Ulah manusia yang mengeksploitasi sumber daya alam berlebihan serta gejala maupun proses alam merupakan tanda-tanda dari bencana alam (Suyadi, 2010), (Tondobala, 2011). Dari hal tersebut, persepsi mengenai bencana alam adalah kemampuan individu dalam memahami dan mencerna beragam gejala atau proses alam yang terjadi sebagai akibat yang muncul dari proses alamiah alam itu sendiri maupun ulah manusia yang mengeksploitasi sumber daya alam secara berlebihan.

Dalam menciptakan pemahaman anak serta keterampilan anak untuk mampu melindungi dirinya sendiri dari bencana, maka perlu meningkatkan pengetahuan serta pengertian anak terhadap beragam hal mengenai bencana, seperti definisi bencana, penyebab terjadinya bencana, dan bagaimana anak seharusnya mampu melindungi dirinya sendiri dari bencana. Dalam hal ini, dibutuhkan ruang dan waktu bagi anak dalam mengimplementasikan apa yang telah ia ketahui. Sehingga, hal tersebut dapat diajari kepada anak melalui beragam metode pembelajaran mengenai mitigasi bencana untuk anak seperti yang disampaikan dalam bukunya Inten. D.N, et al : 2021, yang menyebutkan terdapat gabungan tiga metode pembelajaran, yakni melalui metode bernyanyi, bercerita, serta bermain. Metode ini mampu melibatkan anak secara langsung dalam pembelajaran yang dikemas melalui permainan dan demonstrasi bencana sehingga anak dapat diikutsertakan secara aktif dalam cerita-cerita mengenai kebencanaan yang bermanfaat dalam meningkatkan pemahaman anak dalam mengetahui bagaimana caranya melindungi diri ketika bencana datang.

\section{Melakukan Diskusi Dengan Anak Terkait Bencana}

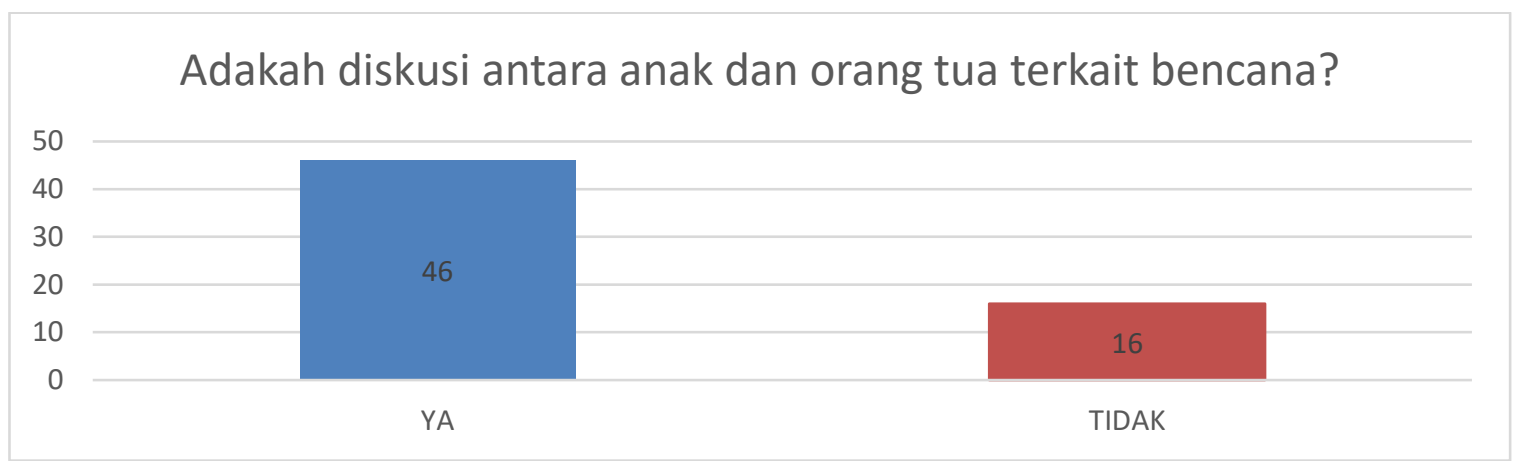

Grafik 3. Diskusi Orang Tua dengan Anak tentang Bencana

Grafik 3 menjelaskan hasil kuesioner yang disebarkan kepada 62 orang tua dari anak usia dini yang tersebar di Kabupaten Bandung, diperoleh jawaban bahwa terdapat 74,2\% orang tua banyak berdiskusi dengan anak tentang bencana; dan $25,8 \%$ orang tua yang tidak berdiskusi dengan anak. Orang terdekat dan model utama dalam pendidikan anak usia dini adalah orang tua, sehingga melalui diskusi atau berbincang santai antara orang tua dan anak tanpa sekat mampu mendudukkan orang tua sebagai kawan bagi anaknya. Hal ini mampu menjadikan anak merasa nyaman sehingga ia mampu menyampaikan ide, perasaan, dan apa yang telah ia ketahui terkait bencana. Inten. D.N: 2017, menyampaikan gagasan bahwa dalam membangun komunikasi yang efektif dalam edukasi anak usia dini adalah menggunakan metode bermain peran yang mampu menciptakan rasa aman, nyaman, dan tidak takut salah untuk memerankan karakter-karakter yang disampaikan melalui cerita.

Merehabilitasi kesehatan psikis maupun mental bagi anak korban bencana bukan perkara yang mudah. Dibutuhkan metode yang tepat serta jangka waktu yang panjang untuk menangani anak-anak dalam mengatasi dampak dari bencana. Di samping itu, dalam 
pemulihan dampak trauma mental pada anak lebih rumit dibandingkan dampak fisik. Dalam hal ini, anak-anak mengalami banyak kejadian yang dapat mempengaruhi mentalnya, seperti kehilangan anggota keluarga, pendidikan, teman bermain, kesenangan, lingkungan bermain yang sudah rusak, bahkan kehilangan harapan atas masa depan. Untuk itu, diperlukan pula rancangan program khusus untuk anak-anak dengan menggunakan konsep trauma healing yang dapat dilakukan dengan menciptakan playgroup dengan melakukan beragam kegiatan bermain, belajar, melakukan kegiatan seni, menggambar, dan hal-hal positif lain untuk mengisi waktu luang anak dan sebagai bentuk mengekspresikan emosi yang terpendam dalam diri anak selama menghadapi bencana.

Seperti halnya diterapkan kepada anak-anak korban pada peristiwa bencana gunung meletus, dalam menerapkan metode trauma healing, ketika menanyakan kepada anak-anak terkait perasaannya ketika gunung meletus, mereka terlihat ketakutan, dan ketika mereka melakukan kegiatan menyenangkan seperti bernyanyi, menggambar, dan mewarnai, mereka menunjukkan ekspresi bahagia. Hasil penelitian membuktikan bahwa senandung yang di hariringkan seorang ibu kepada anaknya semasa kecil akan menjadi memori terindah dan isi senandung tersebut akan diingat anak sampai dewasa bahkan akan menjadi doa-doa agar anak dapat kuat bertahan menjalani kehidupannya (Permatasari. A.N. \& Inten. D.N: 2020). Selain itu, di saat terjadi suatu bencana, kita dapat memberikan edukasi mengenai nilai-nilai moral seperti menjalin kerjasama, leadership, rasa saling memiliki, dan rasa erat persaudaraan dengan mengajak anak-anak melakukan beragam permainan seperti ular tangga dan lomba balon berjalin (Edwin, 2017). Untuk melatih kesabaran dan melupakan kesedihan, anak-anak dapat diberikan beragam kegiatan baru yang menyenangkan dan menyibukkan anak-anak (Nasution et al., 2014).

\section{Mengingatkan Anak untuk selalu Bersyukur dan Bersabar}

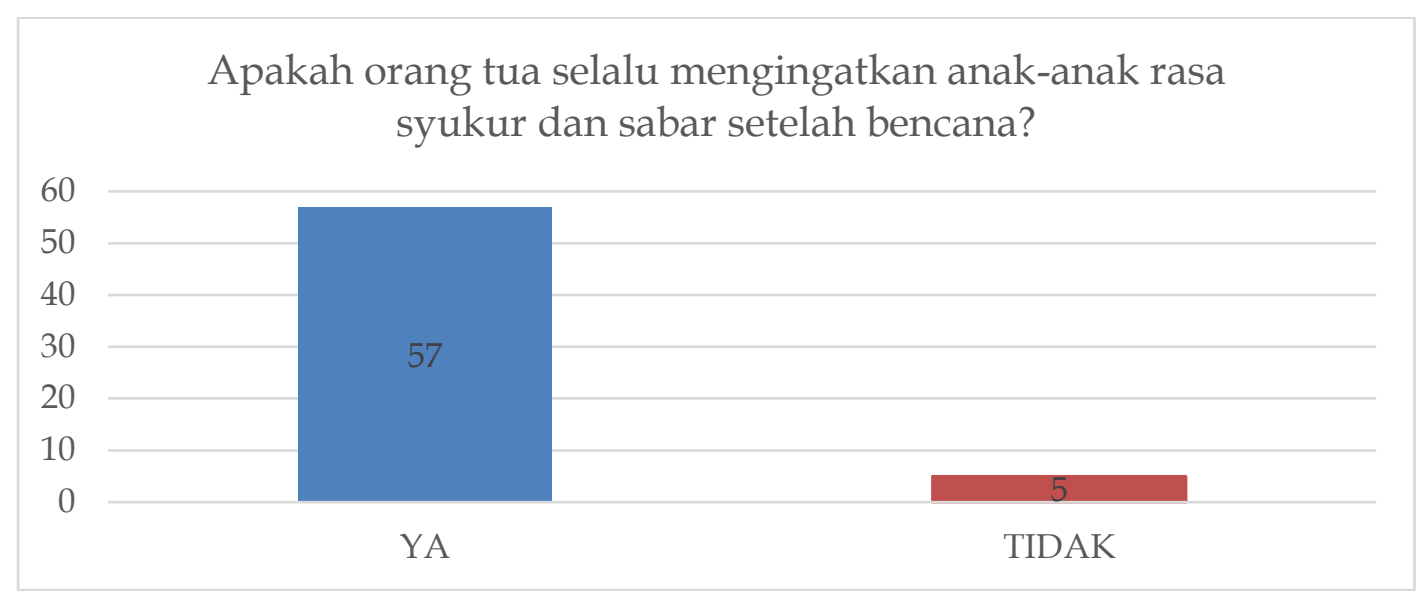

Grafik 4. Orang Tua Mengingatkan Anak untuk Selalu Syukur dan Sabar

Grafik 4 merupakan hasil kuesioner yang disebarkan kepada 62 orang tua dari anak usia dini yang tersebar di Kabupaten Bandung, diperoleh jawaban bahwa terdapat 91,9\% orang tua selalu mengingatkan anak untuk selalu bersyukur dan bersabar atas bencana yang terjadi; dan $8,1 \%$ orang tua tidak mengajarkan anak untuk selalu bersyukur dan bersabar atas bencana yang terjadi. Hal utama yang perlu diperhatikan dalam edukasi anak usia dini adalah percontohan atau model yang diperlihatkan oleh orang dewasa di sekeliling anak. Model ini dapat berupa orang tua, guru, mentor, atau bahkan public figure yang diidolakan anak. Pada masa ini, apabila mereka mampu memberikan perasaan aman, nyaman, dan rasa tenang kepada anak, maka anak akan berani bersandar dan meniru perlakuan yang didapatkan dari mereka. Dengan ini, perlu contoh yang mampu membuat anak bersyukur dan bersabar yang diberikan oleh orang tua agar anak mampu menirunya. Berdasarkan hasil penelitian Inten, 
D.N. 2017: sifat anak usia dini memperhatikan, mengamati, dan mencontoh beragam perilaku yang ditunjukkan orang tua dan figur orang tua terdekat akan terus melekat sepanjang hidupnya, sehingga apabila orang tua menuntut anak jujur maka orang tua pun harus melakukan hal yang sama.

Jika dipandang dari segi psikis, gangguan psikis rentan menyerang anak-anak. Alam bawah sadar menjadi tempat mengendapnya kenangan traumatis ketika bencana datang. Gejala gangguan psikis pada anak antara lain dapat terlihat ketika anak terlihat murung, kesulitan tidur, dan nafsu makan yang buruk. Anak-anak yang memperlihatkan gejala ini perlu mendapatkan penanganan terapi karena apabila diabaikan maka dapat menimbulkan dampak jangka panjang dan akan semakin terlihat ketika mereka beranjak dewasa (Astuti, 2012). Namun semua itu dapat diminimalisir jika anak memiliki orang tua yang terbiasa, mencontohkan dan membiasakan anak untuk menjadi individu yang kuat, bertahan dan mengembalikan segalanya kepada sang Khalik yang pasti memberikan yang terbaik untuk setiap hamba-Nya.

Risiko terhadap anak-anak yang menjadi korban bencana dapat dihindari dengan cara melakukan pendampingan secara langsung sehingga dapat mengajarkan anak-anak untuk saling berbagi dan hal itu dapat menjadikan anak diperhatikan sehingga mampu membuat anak-anak yang mengalami trauma merasakan rasa aman dan nyaman kembali (Mulyadi, 2012). Berdasarkan hasil kuesioner yang disebarkan kepada 62 orang tua dari anak usia dini yang tersebar di Kabupaten Bandung, diperoleh jawaban bahwa terdapat $79 \%$ adanya perubahan yang terjadi pada anak pasca pembelajaran mitigasi bencana; dan $21 \%$ anak tidak ada perubahan sama sekali. Model pembelajaran mitigasi bencana menggunakan pendekatan yang sesuai dengan anak dan metode yang kreatif dan menyenangkan tidak sekadar memberikan pengetahuan terkait kebencanaan dan mengaplikasikannya dalam kehidupan anak saja. Hasil penelitian menyebutkan jika pendekatan terpadu dengan menggunakan model mitigasi katumbiri yang sesuai dengan perkembangan anak, penggunaan tiga metode (bernyanyi, bermain bercerita) disertai dengan integrasi nilai-nilai Islam dapat meningkatkan skills dan pemahaman anak dalam mitigasi bencana (Inten, D.N, et al : 2021).

\section{Meminta Anak untuk Menyanyikan Lagu}

Menikmati lagu memang kegiatan yang paling mengasyikkan. Lagu yang diringi dengan musik ternyata menularkan kemajuan IQ (Intelligent Quotion) dan EQ (Emotional Quotion) seseorang. Seorang anak yang tidak terbiasa mendengar lagu diiringi musik tidak lebih berkembang dibandingkan dengan seorang anak yang telah terbiasa mendengarkan lagu diiringi dengan musik sedari kecil. Selain itu, sama halnya dengan anak yang jarang mendengarkan lagu dengan musik tingkat disiplinnya tidak lebih baik dibandingkan anak yang sering mendengarkan lagu dengan musik. Berdasarkan hasil kuesioner yang disebarkan kepada 62 orang tua dari anak usia dini yang tersebar di Kabupaten Bandung, diperoleh jawaban bahwa terdapat $74,2 \%$ orang tua meminta anaknya untuk menyanyikan lagu tentang bencana; dan $25,8 \%$ orang tua yang tidak meminta anaknya untuk menyanyikan lagu tentang bencana. Grafik 5 data berdasarkan grafik.

Hal ini menyatakan bahwa nyanyian dan lagu erat dan dekat dengan dunia anak, serta semua orang bahkan orang tua yang tidak bergelut di bidang pendidikan anak usia dini pun dapat merangkai lagu dan menyenandungkan syair lagu yang menarik bagi anak. Melalui perkembangan kecerdasan yang dimiliki anak akan berdampak positif apabila anak merasakan kegembiraan dan kesenangan yang ditularkan dari lagu dan nyanyian. Beberapa penelitian membuktikan: Inten. D.N. 2018, Salah satu alternatif metode edukasi untuk anak usia 2 dan tiga tahun adalah puisi lagu. Pengembangan minat anak terhadap literasi dan aksara dapat didukung dengan pengajaran literasi sedari dini melalui metode bernyanyi karena hal tersebut disukai dan relevan untuk anak usia dini (Inten. D.N, eta al : 2016). 


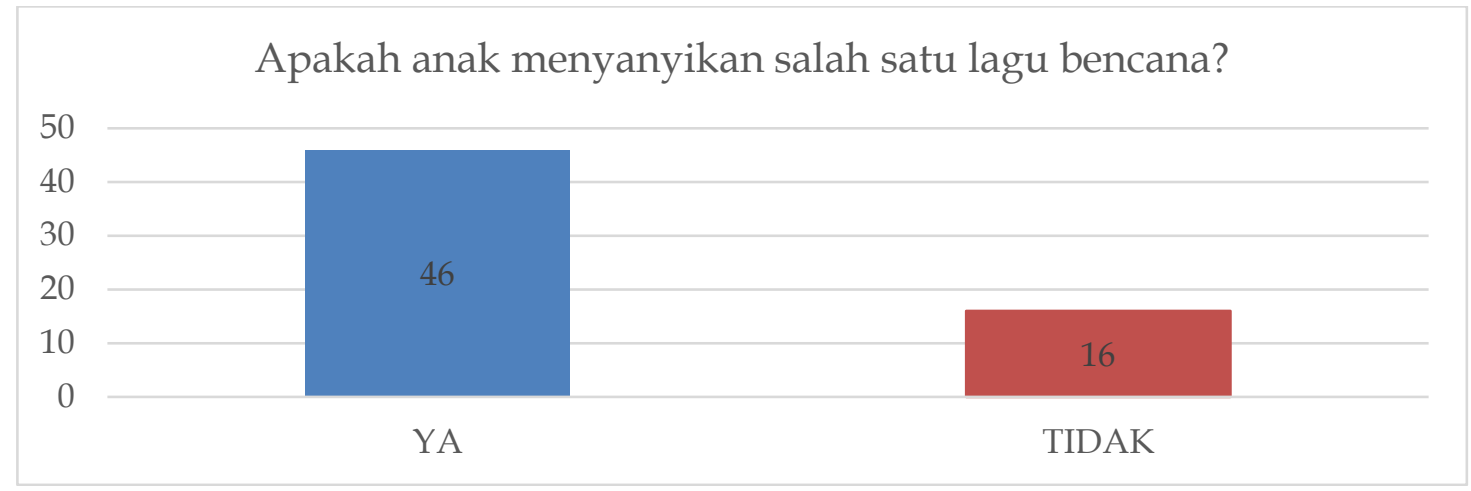

Grafik 5. Anak Menyanyi Lagu Bencana

Sesuai dengan topik bencana, sebaiknya anak dilibatkan dalam menyanyikan lagu. Beberapa langkah sistematis yang dapat direalisasikan untuk menulis lagu anak-anak, yaitu: 1) Menentukan tema lirik dari lagu terlebih dahulu. Apabila lagu menceritakan tentang keindahan alam, maka melodinya akan terdengar gembira. Namun, apabila menulis lirik lagu yang berisi doa, maka karakter melodi yang dibawakan akan bersifat mulia atau luhur; 2) Interval lagu anak-anak juga tidak melebihi satu oktaf; 3) Tema lagu menyesuaikan dengan ritme yang sederhana; 4) Memilih kata-kata yang sederhana dan mudah dipahami dalam menyusun lirik lagu untuk anak, misalnya "menggapai hari esok", "capailah citamu setinggi langit", dan "bekerja keras membanting tulang" (Kusumawati \& Sari, 2012).

\section{Meminta Anak Membaca Al-Qur'an/ Hadits/ Mahfudzhat tentang Bencana}

Selain menyanyikan lagu tentang bencana, sebagai muslim yang memiliki keimanan akan dzat yang mengatur segalanya, yakni Allah. Maka sebaiknya anak diminta/ dikenalkan dengan ayat/ hadits/ mahfudzhat yang ada kaitannya dengan bencana. Berdasarkan hasil kuesioner yang disebarkan kepada 62 orang tua dari anak usia dini yang tersebar di Kabupaten Bandung, diperoleh jawaban bahwa terdapat $72,6 \%$ anak diminta untuk melafalkan ayat Al-Qur' an/ Hadits/ Mahfudzhat tentang bencana; dan 27,4\% orang tua tidak meminta anaknya untuk melakukan hal demikian, berikut merupakan penjelasan data menggunakan grafik.

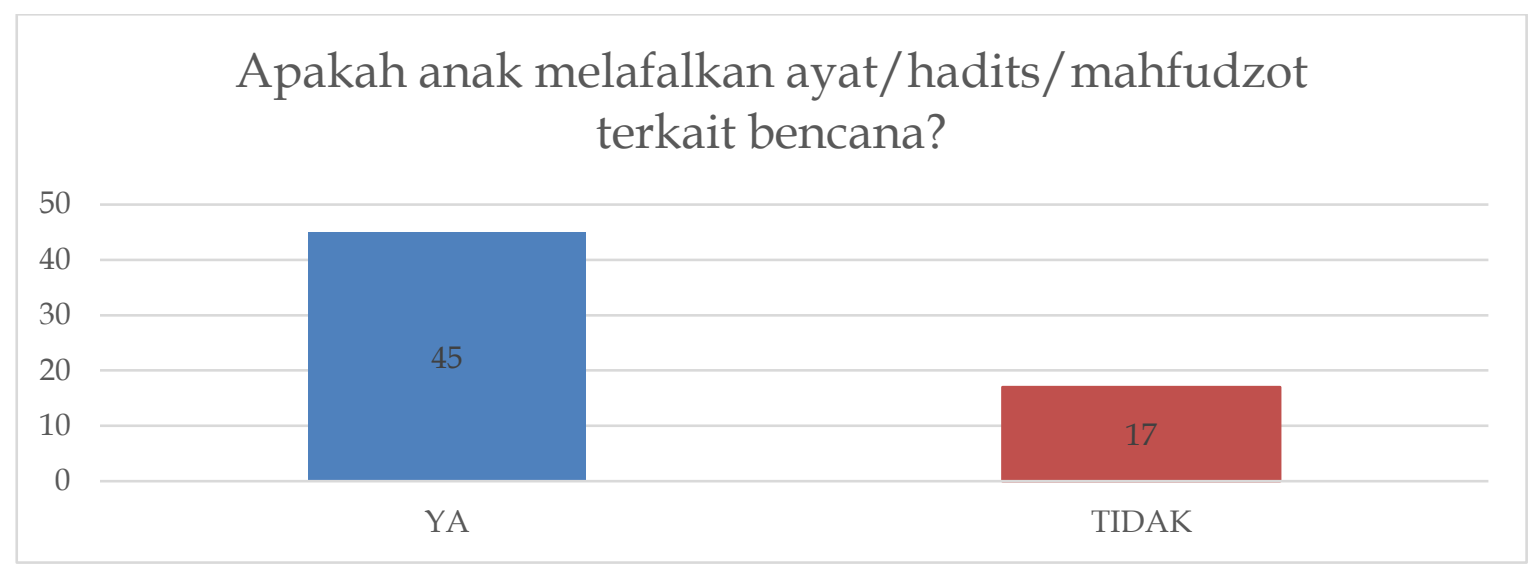

Grafik 6. Anak Melafalkan Ayat/ hadits/ Mahfudzhat tentang Bencana

Bencana alam yang terjadi tidak terhindar dari unsur kausalitas dan telah menjadi ketentuan Allah SWT sebagai bentuk kekuasaan-Nya terhadap alam semesta (sunnatullah fi alkaun). Seperti yang dijelaskan oleh para ulama, bahwa terdapat hubungan antara tingkah laku manusia dengan bencana alam yang terjadi di bumi dengan dosa manusia (Khambali, 2017) . 
Banyak ayat dalam Al-Quran yang telah menjelaskan dan menggambarkan betapa luar biasanya bencana alam yang terjadi dan menimpa umat-umat di masa lalu, seperti: perubahan bentuk jasad (al-maskh) (Kaum Yahudi-Ashab As-Sabt), angin topan (al-rih al-'aqim) (Kaum Nuh, Kaum 'Ad), suara pekikan (al-shaihah) (Kaum Tsamud, Kaum Nabi Syu'aib, Kaum Nabi Luth), awan panas (al-zhillah) (Kaum Nabi Syu'aib/ Madyan), penenggelaman ke bumi (al-khasf) (Qarun), halilintar (al-shä'iqah) (Kaum Tsamud), bumi yang dibalik (qalb aldiyār) (Kaum Nabi Luth), gempa bumi (al-rajfah) (Kaum Tsamud, Kaum Nabi Syu'aib (Kaum Madyan), penenggelaman (al-gharq) (Kaum Nuh dan Fir'aun), dan hujan batu (al-hijārah) (Kaum Nabi Luth dan Ashab Al-Fiil/ Raja Abraha.

Bencana-bencana yang digambarkan dalam Al-Quran tersebut merupakan bencana yang kuat hubungannya dengan perbuatan manusia di masa itu. Al-Quran telah menjelaskan bahwa penyebab-penyebab umum yang melatarbelakangi bencana-bencana hebat tersebut antara lain: kesalahan-kesalahan (alkhathāyā), dosa-dosa (al-dzunūb), kezaliman (al-zhulm), perbuatan dosa (al-ijrām), kekafiran (al-kufr), kefasikan (al-fisq), dan kerusakan (al-fasād).

Selain beberapa faktor bencana yang telah disebutkan, terdapat faktor-faktor penyebab lain yaitu kemaksiatan yang secara spesifik disebutkan ayat-ayat dalam Al-Quran, di antaranya: kufur nikmat, kesombongan (al-istikbär), pendustaan (al-takdzīb), kesyirikan (alsyirk), mengolok-olok para rasul dan para pengikutnya yang beriman (al-istihzā bi al-rusul wa atba'ihim), melukai para rasul dan para pengikutnya yang beriman (al-ìdzā bi al-rusul wa atba'́ihim), menerjang sekat larangan Allah Swt., perbuatan mengurangi timbangan, dan perbuatan homoseksual.

Berdasarkan uraian tersebut, maka sebagai orang tua perlu memberikan pendampingan moral dan spiritual kepada anaknya. Selain agar dekat dengan Allah, maka secara tidak langsung anak akan membangun hubungan semakin baik dengan orang tuanya.

Pada saat pandemic orang tua dan anak melakukan berbagai aktivitas di rumah maka hal ini merupakan kesempatan yang berharga bagi orang tua untuk melakukan perannya sebagai pendidik utama bagi anak. Melalui berbagai kegiatan melibatkan orang tua dan anak akan membantu terjalinnya hubungan yang harmonis serta anak akan merasakan kenyamanan dalam pembelajaran dikarenakan ada oreng tua yang merupakan teladan utama dalam kehidupannya. Berdasarkan hasil kuesioner yang disebarkan kepada 62 orang tua dari anak usia dini yang tersebar di Kabupaten Bandung, diperoleh jawaban bahwa terdapat 91,9\% anak dengan orang tua semakin baik kedekatannya; dan 8,1\% kedekatan anak dan orang tua tidak menjadi lebih baik. Berdasarkan hasil penelitian Permatasari, A.N, et al : 2021 membuktikan bahwa kelekatan dan keintiman komunikasi orang tua dan anak akan terjalin Ketika orang tua dapat memerankan tugas yang seharusnya dilakukan. Berikut adalah grafik data berdasarkan questioner.

Apakah dengan adanya bencana kelekatan anak dan orang tua terjalin semakin baik?

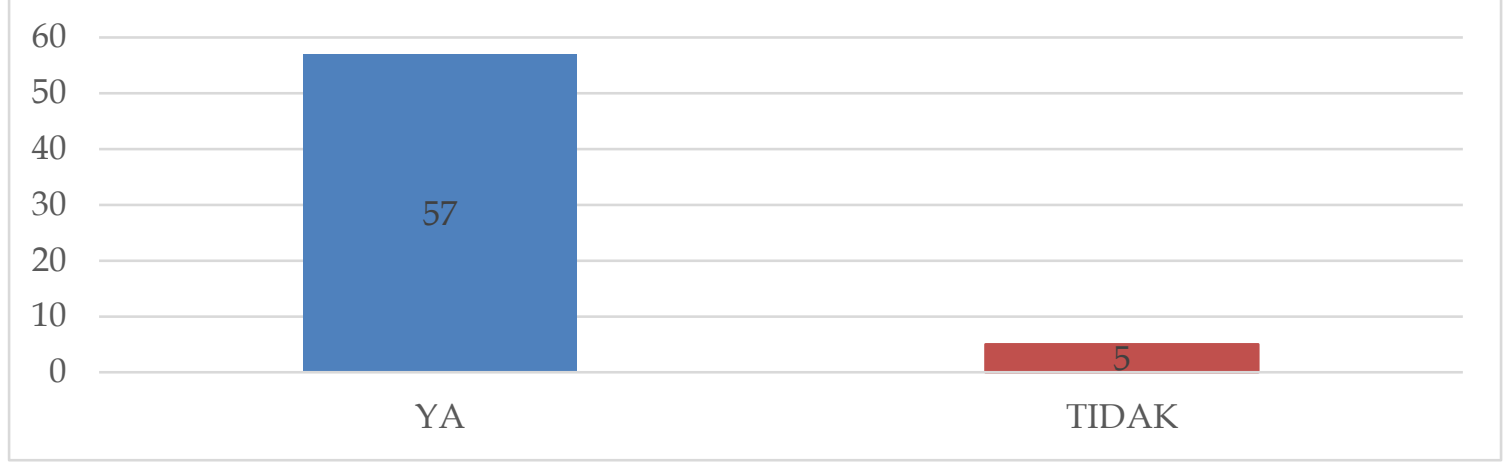

Grafik 7. Kelekatan Anak dan Orang Tua 


\section{Membuat Media tertentu tentang Kebencanaan}

Dalam usaha untuk mengubah siswa untuk meraih suatu kondisi ideal dan positif, maka edukasi digunakan sebagai suatu alat mengorganisasikan beragam komponen. Materi, sebagai syarat pembelajaran, meliputi bahan ajar serta media yang digunakan untuk pembelajaran (Sutjiono, 2005). Dalam mengoptimalisasikan manfaat dari penggunaan media dalam pembelajara, maka diperlukan pemilihan media yang cocok, anggaran biaya, dukungan, inovasi, serta teknologi yang menunjang. Dalam hal ini, buku menjadi media yang tepat karena memuat aspek-aspek tersebut. Sebagai media yang mudah diakses dan digunakan, buku menjadi media yang murah dan didukung oleh pemerintah sebagai penyelenggara pendidikan serta tidak memerlukan media lain untuk mengaksesnya, sehingga perihal akses, biaya, dukungan, dan inovasi dapat diatasi seluruhnya.

Berdasarkan hasil kuesioner yang disebarkan kepada 62 orang tua dari anak usia dini yang tersebar di Kabupaten Bandung, diperoleh jawaban bahwa terdapat $54,8 \%$ orang tua dan anak membuat media tentang bencana; dan $45,2 \%$ orang tua dan anak tidak membuat media tertentu tentang kebencanaan. Dalam hal ini, anak usia dini masih memiliki keterbahasan dalam kemampuan berpikir abstraknya, sehingga media dibutuhkan sebagai bagian dari proses pembelajaran bagi mereka. Dalam memudahkan anak ketika memahami suatu materi belajar, maka penggunaan media penting dalam menyampaikan pesan dan informasi terkait bencana karena dapat disampaikan secara nyata dan jelas. Dalam pembelajaran mitigasi bencana, beberapa media yang dapat digunakan antara lain: boneka jari atau boneka tangan, puzzle kebencanaan, buku cerita yang memuat tema terkait kebencanaan, kartu bergambar kebencanaan, gerak dan nyanyian yang digunakan dalam kegiatan bernyanyi, ular tangga kebencanaan, poster, video, dan simbol kebencanaan serta perangkat kit kebencanaan (Inten, D.N., et al : 2021).

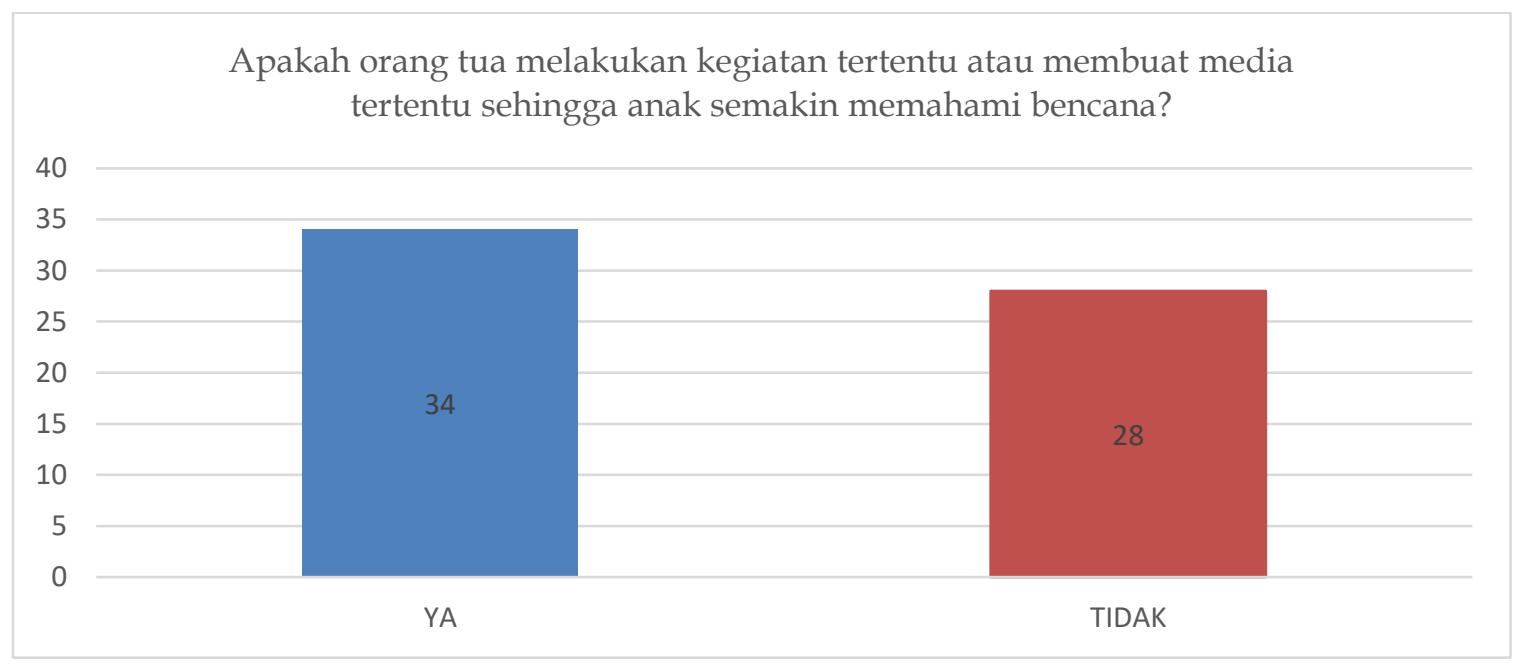

Grafik 8. Orang Tua Membuat Media Mitigasi Bencana

Pembelajaran pendidikan mitigasi yang dilaksanakan di masyarakat diperlukan peran dari narasumber, keaktifan masyarakat, dan inovasi dalam pembelajaran antara lain penggunaan media pembelajaran dan metode pembelajaran. Salah satu komponen komunikasi yang dapat menyampaikan pesan dari komunikator kepada komunikan adalah media pembelajaran (Daryanto, 2013). Dari semua pemaparan tersebut, inti pembahasan ini memperlihatkan jika media pembelajaran menjadi alat yang sangat membantu dalam rangkaian edukasi mitigasi bencana dan memiliki fungsi dalam hal menjelaskan makna pesan yang ingin disampaikan kepada anak usia dini dengan luaran akhir mampu mencapai tujuan pembelajaran yang sempurna dan dapat diterapkan oleh anak ketika bencana terjadi. 


\section{SIMPULAN}

Peran orang tua dalam pembelajaran mitigasi bencana di rumah di masa Covid-19 ini sangat penting dalam ketercapaian tujuan pembelelajaran. Peran orang tua dalam menyukseskan pembelajaran mitigasi bencana di masa Covid-19, dengan cara: menyiapkan tas siaga bencana, meminta anak untuk bercerita tentang kegiatan sekolah terkait mitigasi bencana, anak menyanyikan lagu yang terkait dengan mitigasi bencana, anak melafalkan ayat Al-Qur'an, hadits dan mahfudzhat terkait dengan mitigasi bencana, berdiskusi dengan anak terkait mitigasi bencana; orang tua mengajarkan selalu bersyukur dan bersabar atas setiap musibah yang terjadi; dan orang tua membantu menyiapkan media pembelajaran terkait mitigasi bencana. Sehingga dengan semua hal tersebut kelekatan orang tua dan anakpun dapat terjalin dengan baik.

\section{UCAPAN TERIMA KASIH}

Terima kasih kepada Pimpinan Fakultas Tarbiyah dan Keguruan Universitas Islam Bandung serta Pimpinan Universitas Islam Bandung yang telah mendukung dan memfasilitasi sehingga penelitian ini dapat terlaksana.

\section{DAFTAR PUSTAKA}

Astuti, R. T. (2012). Pengalaman Traumatic Remaja Perempuan Akibat Banjir Lahar Dingin Pasca Erupsi Gunung Merapi Dalam Perspektif Tumbuh Kembang Di Hunian Sementara Kabupaten Magelang.

BPBD. (2019). Tas Siaga Bencana. https://bpbd.temanggungkab.go.id//home/berita/212/tas-siaga-bencana

Bryant, R. A., Gibbs, L., Gallagher, H. C., Pattison, P., Lusher, D., MacDougall, C., Harms, L., Block, K., Sinnott, V., Ireton, G., Richardson, J., \& Forbes, D. (2018). Longitudinal study of changing psychological outcomes following the Victorian Black Saturday bushfires. Australian and New Zealand Journal of Psychiatry, 52(6), 542-551. https:// doi.org/10.1177/0004867417714337

Candra, A. N., Sofia, A., \& Anggraini, G. F. (2017). Gaya Pengasuhan Orang Tua pada Anak usia Dini. Jurnal Pendidikan Anak, 3(2).

CNN Indonesia. (2020). Update Corona 30 April 10118 Positif 792 Meninggal Dunia. https://www.cnnindonesia.com/nasional/20200430132023-20-498858/updatecorona-30-april-10118-positif-792-meninggal-dunia

CRED. (2018). Natural Disasters 2018: An opportunity to prepare. Emergency Events Database. https://www.emdat.be/

Daryanto. (2013). Media Pembelajaran. Gava Media.

Edwin. (2017). Pemulihan Anak Pasca Bencana: Pelibatan Komunitas untuk Hasil Intervensi yang Efektif. (Medan). Fakultas Psikologi USU.

Fothergill, A. (2017). Children, Youth, and Disaster Children, Youth, and Disaster Children, Youth, and Disaster. Oxford Research Encyclopedia of Natural Hazard Science, July 2017, 1-26. https://doi.org/10.1093/acrefore/9780199389407.013.23

GFDRR. (2020). Indonesia. 2020.

Greenberg, N., Carr, J. A., \& Summers, C. H. (2002). Ecology and Evolutionary Biology Ethological Causes and Consequences of the Stress Response Ethological Causes and Consequences of the Stress Response. Integrative \& Comparative Biology. https:// doi.org/10.1093/icb/42.3.508

Hajrah. (2018). Pengembangan metode bercerita pada anak usia dini (Universitas Negeri Makassar: eprints, 25 Oktober 2018). Universitas Negeri MakassarMakassar.

Haleemunnissa, S., Didel, S., Swami, M. K., Singh, K., \& Vyas, V. (2021). Children and COVID19: Understanding impact on the growth trajectory of an evolving generation. 
Children and Youth Services Review,

120. https://doi.org/10.1016/j.childyouth.2020.105754

Havis, D. P. (2020). Perancangan Tas Siaga Bencana Dengan Mempertimbangkan Tas Siaga Bencana.

Hayudityas, B. (2020). Pentingnya penerapan pendidikan mitigasi bencana di Sekolah untuk mengetahui kesiapsiagaan peserta didik. Jurnal Edukasi Nonformal, 1(2)(Anak dan Bencana), 94-102.

International Insurance Institute. (2020). Facts + Statistics: Global catastrophes. 2020.

Kementerian Kesehatan RI. (2020). Pedoman Pencegahan dan Pengendalian Corona Virus deases (Covid-19). Kementrian Kesehatan, 178. https://covid19.go.id/storage/app/media/Protokol/REV05_Pedoman_P2_COVID-19_13_Juli_2020.pdf

Khambali, K. (2017). Family Role in Shaping Character Islam in Early Childhood Through Habituation Method. Ta Dib: Jurnal Pendidikan Islam, 6(1), 155-163. https:// doi.org/10.29313/tjpi.v6i1.2382

Kousky, C. (2016). Impacts of natural disasters on children. Future of Children, 26(1), 73-92. https://doi.org/10.1353/foc.2016.0004

Kumoro, I. (2015). Analisis Urgensi Metode Pembelajaran Bercerita Bagi Perkembangan Empati Anak di TK Dharma Wanita Kendal Tahun Ajaran 2015/2016. Prosiding Seminar Nasional Pendidikan "Meretas Sukses Publikasi Ilmiah Bidang Pendidikan Jurnal Bereputasi," 1(1), 129-131.

Kusumawati, H., \& Sari, E. S. (2012). Pelatihan Penulisan Lagu Anak Untuk Guru-Guru Tksebagai Media Mitigasi Bencana Di Yogyakarta. INOTEK, 16(2).

lestari, S. (2012). Psikologi Keluarga: Penanaman Nilai dan Penanganan Konflik dalam Keluarga,. Jakarta:Prenada Media Group, 50.

Lutfatutatifah, Adriany, V., \& FaizahRomadona, N. (2015). Pola Asuh Orang Tua Anak Usia Dini Di Kampung Adat Benda Kerep Kota Cirebon. Jurnal Pendidikan Serantau, 1(1), 1-226.

Mulyadi. (2012). Perkembangan Anak (11th ed.). Erlangga.

Nasution, Wahyuni, \& Daulay. (2014). Penatalaksanaan Dampak Psikologis Pada Anak Korban Bencana Melalui Terapi Bermain. Studi Kasus Erupsi Gunung Sinabung.

Norris, F. H., Friedman, M. J., Watson, P. J., Byrne, C. M., Diaz, E., \& Kaniasty, K. (2002). 60,000 Disaster victims speak: Part I. An empirical review of the empirical literature, 19812001. Psychiatry, 65(3), 207-239. https://doi.org/10.1521/psyc.65.3.207.20173

Novrinda, Nina, K., \& Yulidesni. (2017). Peran Orang Tua Dalam Pendidikan Anak Usia Dini. Raudhatul Athfal: Jurnal Pendidikan Islam Anak Usia Dini, 1(1), 61-80. https://doi.org/10.19109/ra.v1i1.1526

Nuraeni, N., Mujiburrahman, M., \& Hariawan, R. (2020). Manajemen Mitigasi Bencana pada Satuan Pendidikan Anak Usia Dini untuk Pengurangan Risiko bencana Gempa Bumi dan Tsunami. Jurnal Penelitian Dan Pengkajian Ilmu Pendidikan: E-Saintika, 4(1), 68. https://doi.org/10.36312/e-saintika.v4i1.200

Nurlaeni, N., \& Juniarti, Y. (2017). Peran Orang Tua Dalam Mengembangkan Kemampuan Bahasa Pada Anak Usia 4-6 Tahun. Jurnal Pelita PAUD, 2(1), 51-62. https://doi.org/10.33222/pelitapaud.v2i1.196

Osofsky, J., \& Reuther, E. (2013). Young Children and Disasters: Lessons Learned About Resilience and Recovery. ZERO TO THREE, 34(2), 46-54.

Pemerintah Republik Indonesia. (2007). Undang-Undang Nomor 24 Tahun 2007 tentang Penanggulangan Bencana. In Pemerintah Republik Indonesia. http://www.litbang.depkes.go.id/sites/download/regulasi/uu/UU_No._24_Th_20 07_ttg_Penanggulangan_Bencana.pdf

Prabhawani, S. W. (2016). Pelibatan Orang Tua Dalam Program Sekolah di TK Khalifah. Jurnal Pendidikan Guru Pendidikan Anak Usia Dini, 2(5), 205-218. 
Rakhmawati, I. (2015). Peran Keluarga dalam Pengasuhan Anak. Jurnal Bimbingan Konseling Islam, 6(1), 1-18. https:// doi.org/10.21043/kr.v6i1.1037

Raynaudo, G., \& Peralta, O. (2019). Children learning a concept with a book and an e-book: a comparison with matched instruction. European Journal of Psychology of Education, 34(1), 87-99. https:// doi.org/10.1007/s10212-018-0370-4

Rijal, A. S., Matalapu, I., Jaya, R., \& Maulana, K. M. (2021). Analisis Mitigasi Bencana terhadap Kondisi Sosial Budaya di Gorontalo. LaGeografia, 19(2), 155-174. https://ojs.unm.ac.id/Lageografia/article/view/17221

Scott, B. G., Lapré, G. E., Marsee, M. A., \& Weems, C. F. (2014). Aggressive Behavior and Its Associations With Posttraumatic Stress and Academic Achievement Following a Natural Disaster. Journal of Clinical Child and Adolescent Psychology, 43(1), 43-50. https:// doi.org/10.1080/15374416.2013.807733

Shultz, J. M., Espinola, M., Rechkemmer, A., Cohen, M. A., \& Espinel, Z. (2017). Prevention of Disaster Impact and Outcome Cascades. In M. Israelashvili \& J. Romano (Eds.), The Cambridge Handbook of International Prevention Science (pp. 492-519). Cambridge University Press. https://doi.org/10.1017/9781316104453.022

Strouse, G. A., Nyhout, A., \& Ganea, P. A. (2018). The role of book features in young children's transfer of information from picture books to real-world contexts. In Frontiers in Psychology (Vol. 9, Issue FEB). https:// doi.org/10.3389/fpsyg.2018.00050

Sutjiono, T. W. A. (2005). Pendayagunaan Media Pembelajaran. Jurnal Pendidikan Penabur, 7(04), 76-84.

Suyadi. (2010). Psikologi Belajar PAUD. Pustaka Insan Madani.

Tondobala, L. (2011). Pendekatan Untuk Menentukan Kawasan Rawan Bencana di Pulau Sulawesi. Jurnal Sabua, 3(3), 40-52.

UNDP. (2020). One of the world's most disaster-prone countries, Indonesia prepares school for tsunamis.

Https://Www.Id.Undp.Org/Content/Indonesia/En/Home/Presscenter/Articles/2 018/One-of-the-World-s-Most-Disaster-Prone-Countries--Indonesia-Prep.Html.

Utomo, A. P. (2020, March). WHO Umumkan Virus Corona sebagai Pandemi Global. Kompas.

World Health Organization. (2020). Coronavirus disease 2019. World Health Organization. https://www.who.int/emergencies/diseases/novel-coronavirus-2019 